University of Nebraska - Lincoln

DigitalCommons@University of Nebraska - Lincoln

USDA Wildlife Services - Staff Publications

U.S. Department of Agriculture: Animal and Plant Health Inspection Service

2013

\title{
Leptospirosis in Fox Squirrels (Sciurus niger) of Larimer County, Colorado, USA
}

\author{
Katherine Dirsmith \\ Colorado State University \\ Kaci K. VanDalen \\ USDA/APHIS/WS National Wildlife Research Center, kaci.vandalen@aphis.usda.gov \\ Tricia Fry \\ US Department of Agriculture \\ Brad Charles \\ Colorado State University \\ Kurt C. VerCauteren \\ USDA-APHIS-Wildlife Services, kurt.c.vercauteren@usda.gov
}

See next page for additional authors

Follow this and additional works at: https://digitalcommons.unl.edu/icwdm_usdanwrc

Part of the Life Sciences Commons

Dirsmith, Katherine; VanDalen, Kaci K.; Fry, Tricia; Charles, Brad; VerCauteren, Kurt C.; and Duncan, Colleen, "Leptospirosis in Fox Squirrels (Sciurus niger) of Larimer County, Colorado, USA" (2013). USDA Wildlife Services - Staff Publications. 1461.

https://digitalcommons.unl.edu/icwdm_usdanwrc/1461

This Article is brought to you for free and open access by the U.S. Department of Agriculture: Animal and Plant Health Inspection Service at DigitalCommons@University of Nebraska - Lincoln. It has been accepted for inclusion in USDA Wildlife Services - Staff Publications by an authorized administrator of DigitalCommons@University of Nebraska - Lincoln. 


\section{Authors}

Katherine Dirsmith, Kaci K. VanDalen, Tricia Fry, Brad Charles, Kurt C. VerCauteren, and Colleen Duncan 


\section{Leptospirosis in Fox Squirrels (Sciurus niger) of Larimer County, Colorado, USA}

Katherine Dirsmith, ${ }^{1}$ Kaci VanDalen, ${ }^{2}$ Tricia Fry, ${ }^{2}$ Brad Charles, ${ }^{1}$ Kurt VerCauteren, ${ }^{2}$ and Colleen Duncan ${ }^{1,3}$ ${ }^{1}$ College of Veterinary Medicine and Biomedical Sciences, Colorado State University, 1601 Campus Delivery, Fort Collins, Colorado, USA 80523; '2US Department of Agriculture, Animal and Plant Health Inspection Service, National Wildlife Research Center, 4101 LaPorte Ave., Fort Collins, Colorado, USA 80521; ${ }^{3}$ Corresponding author (email: colleen.duncan@ colostate.edu)

ABSTRACT: Leptospirosis is a zoonotic disease caused by the bacterium Leptospira interrogans. The organism is typically maintained within a geographic region by colonizing renal tubules of carrier animals and shed into the environment in urine. We assessed whether L. interrogans was present in fox squirrels (Sciurus niger) in Larimer County, Colorado, USA, and whether it is associated with disease. Twenty-two squirrels were trapped from 29 November 2011 to 15 December 2011 for use in an unrelated study. The squirrels were individually housed for 33-65 days and euthanized; no clinical disease was observed. On gross examination, significant renal lesions were observed in 6 of 22 animals (27\%). Histologically, affected animals had severe neutrophilic tubulitis with interstitial nephritis. Immunohistochemistry was conducted on the kidneys of all animals and 10 of 22 (45\%) were positive for $L$. interrogans, with varying severity of infection. The same 10 squirrels were serologically positive for antibodies specific to $L$. interrogans. These results suggest that $L$. interrogans is present in fox squirrels in Larimer County, Colorado, USA, and may be associated with varying degrees of renal disease. Further investigation into the role of wildlife in the ecology of leptospirosis within the region is warranted.

Key words: Colorado, Leptospira interrogans, leptospirosis, squirrel, wildlife.

Leptospirosis is a disease caused by gram-negative bacteria of the genus Leptospira. The pathogen is maintained in a wide range of wild and domestic animal hosts, such as dogs (Canis lupus familiaris), livestock, and rodents (Rodentia; Lau et al., 2009). In geographically distinct populations, a single host species may carry several serovars (Bharti et al., 2003). Leptospira spp. are typically maintained by colonization of renal tubules in carrier animals. Although carrier animals may exhibit few or no symptoms, leptospires can be shed in urine (Monahan et al., 2009). Susceptible animals can be infected directly by contact with carrier animals or indirectly by contact with traces of contaminated urine in water sources (Gautam et al., 2010). In the past several decades, Leptospira interrogans has been deemed a globally important zoonotic pathogen (Bharti et al., 2003), occurring in many mammalian species, including humans. Historically, leptospirosis was regarded as an uncommon disease in Larimer County, Colorado, USA, but leptospires have increasingly been identified in domestic canines and raccoons (Procyon lotor; Veir 2009; Duncan et al., 2012). We assessed the prevalence of $L$. interrogans in another peridomestic species, the fox squirrel (Sciurus niger), trapped around homes in Fort Collins, Larimer County, Colorado, USA.

We used Tomahawk live traps $(48 \times$ $15 \times 15 \mathrm{~cm}$; Tomahawk Live Trap Co., Hazelhurst, Wisconsin, USA) baited with peanut butter and oats to trap 22 fox squirrels, 11 males $(\mathrm{M})$ and 11 females $(\mathrm{F})$ from 29 November 2011 to 15 December 2011, for use in an unrelated vaccine research study (Fry, pers. comm.). When accessioned, fox squirrels were dusted for ectoparasites (Drione ${ }^{\circledR}$, Bayer, Montvale, New Jersey, USA) and housed individually in stainless-steel cages $(50 \times 61 \times 42 \mathrm{~cm})$ at the National Wildlife Research Center (NWRC), Animal Research Building (Fort Collins, Colorado, USA). Fox squirrels were fed a diet comprising Purina Rodent Chow (Purina, St. Louis, Missouri, USA), apples, and whole mixed nuts. Water was provided ad libitum. The NWRC's institutional animal care and use committee 
approved all animal trapping, handling, and housing procedures.

As part of the original vaccine study, we observed fox squirrels daily and collected blood samples on day 0 of the study (approximately 22-37 days in captivity) and preceding euthanasia (4 or 28 days later). Fox squirrels were anesthetized using isoflurane before being humanely euthanized via intracardiac injection of an overdose of barbiturates (Beuthanasia ${ }^{\circledR}$, Intervet Inc., Merck Animal Health, Summit, New Jersey, USA). Complete postmortem examinations were conducted and multiple tissues were collected for histologic examination. Tissues were fixed in $10 \%$ neutral-buffered formalin, paraffin embedded, cut at $5 \mu \mathrm{m}$, and examined by light microscopy. A Warthin-Starry silver stain and leptospiral immunohistochemistry (IHC) were performed on renal tissue from each animal. The IHC was conducted using a primary antibody composed of a cocktail of six antisera: Canicola-Hond Utrecht IV, Grippotyphosa-Andaman, Hardjo-Hardojoprajtino, Copenhageni$\mathrm{M} 20^{\mathrm{A}}$, Pomona-Pomona, and BratislavaJez Bratislava (US Department of Agriculture, Animal and Plant Inspection Service, National Veterinary Services Laboratory [NVSL], Ames, Iowa, USA). Sera from all fox squirrels were also tested for antibodies specific to five $L$. interrogans serovars: Canicola, Grippotyphosa, Hardjo, Icterohaemorrhagiae, and Pomona, via a microagglutination test at the NVSL.

Gross examination revealed significant renal lesions in six of 22 animals, $(27 \% ; 5 \mathrm{~F}$, $1 \mathrm{M})$. Bilaterally, the kidneys were mottled with multifocal to coalescing areas of pallor 1-4 $\mathrm{mm}$ diameter. On the cut surface, affected areas extended into the parenchyma. All other organs were grossly within normal limits. Histologically, renal lesions were observed in 10 animals (19\%; $6 \mathrm{~F}$, $4 \mathrm{M})$. In the six squirrels in which gross changes were identified, much of the renal parenchyma was effaced by inflammation (Fig. 1A). The interstitial space was expanded by large aggregates of lymphocytes and plasma cells; within affected regions, many tubules were dilated, and tubular lumens contained aggregates of viable and degenerate neutrophils (Fig. 1B) with varying amounts of tubular degeneration and necrosis. In four other animals $(8 \%$; $1 \mathrm{~F}, 3 \mathrm{M}$ ), there were only mild, patchy aggregates of interstitial lymphocytes and plasma cells, devoid of the tubulitis observed in the more severely affected animals. Additional tissues reviewed histologically included lung, liver, and multiple sections of intestinal tract. There was mildto-moderate, bronchiole-associated hyperplasia of the lymphoid tissue in the lung of five animals; two animals had patchy areas of pulmonary inflammation. Very mild periportal, lymphoplasmacytic inflammation was observed in the liver of 14 squirrels, but the cellular infiltrate did not distort the hepatic parenchyma. Two animals had both enteritis and colitis, which was moderate and mononuclear in nature.

Warthin-Starry silver stain highlighted filamentous organisms on the luminal surface of tubular epithelial cells of four animals with severe tubulitis (Fig. 1C). In the six severely affected animals, there was strong immunostaining of the tubular epithelial cells, both on the luminal membrane, but also cytoplasmically, and patchy staining of leukocytes within the interstitium (Fig. 1D). Minimal immunostaining was observed in four additional animals; mild-to-moderate interstitial inflammation had been observed histologically in these four animals, but none had severe tubulitis.

The six severely affected animals had high titers of circulating antibodies to $L$. interrogans; highest titers were observed against serovars Grippotyphosa, Hardjo, and Icterohaemorrhagiae (Table 1). Sera from four fox squirrels with histologic evidence of a mild infection were also positive for antibodies specific to $L$. interrogans. Two of these fox squirrels were sampled 28 days apart with little or no increase in antibody titers. This mild infection paired with stable antibody titers 

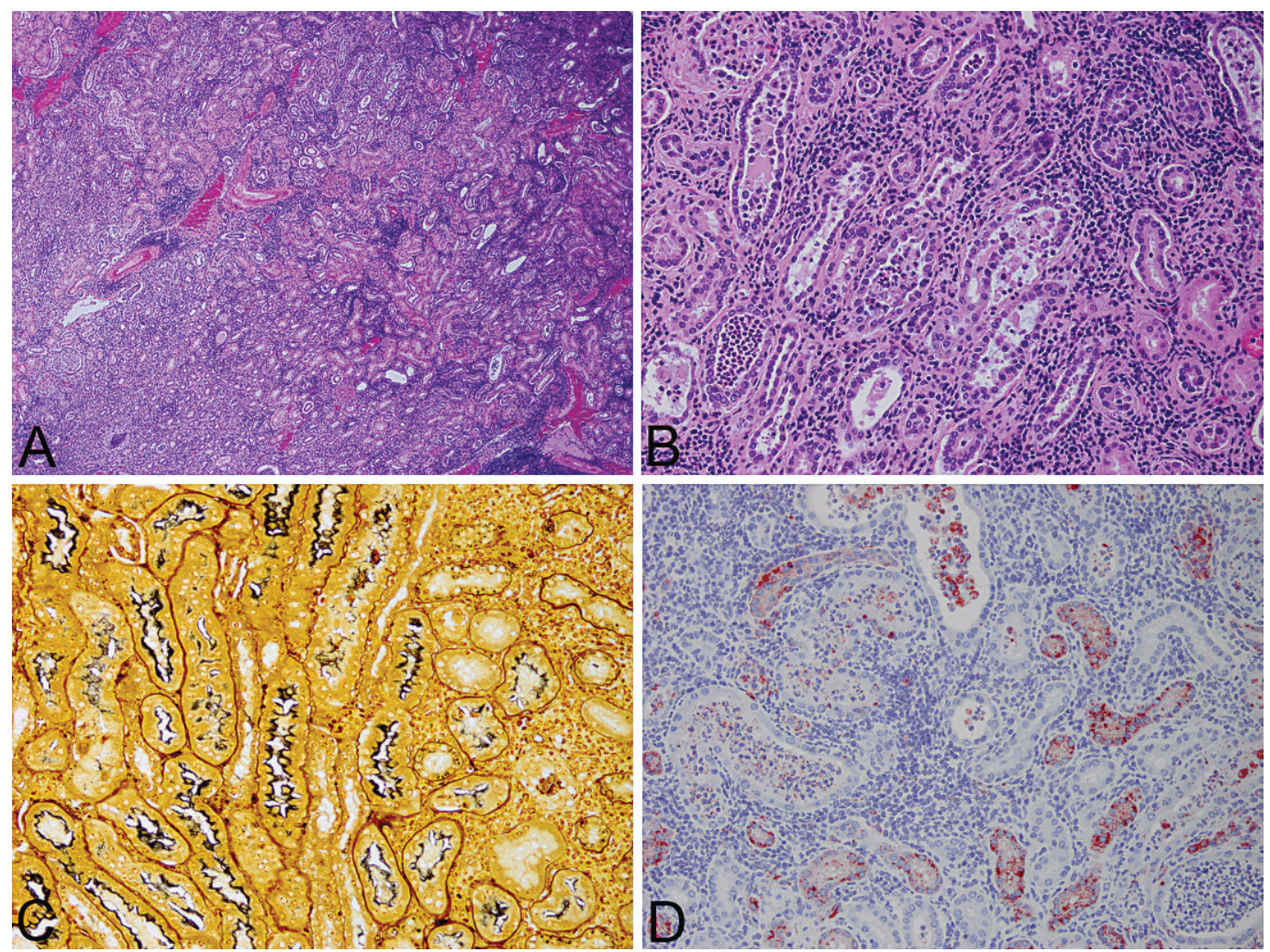

Figure 1. Kidney of a fox squirrel (Sciurus niger) infected with Leptospira interrogans. (A) There is marked inflammation affecting both the interstitium and renal tubules. H\&E. $\times 4$. (B) Inflammatory cells dilate renal tubules and are predominantly neutrophils. H\&E. $\times 20$. (C) Lining renal tubules are many argyrophilic organisms. $\times 20$ Warthin-Starry silver stain. (D) Strong L. interrogans immunostaining is present in the tubular epithelial cells and inflammatory cells in tubular lumens. Immunohistochemistry. $\times 20$.

may be indicative of a "carrier" state or animals recovering from infection. Three individuals with minimal or no histologic evidence of renal disease showed low reactivity (titer $\leq 200$ ) to $L$. interrogans serovars Hardjo or Icterohaemorrhagiae on the last blood collection only. These low and inconsistent titers may indicate a possible exposure while in captivity, recovery from infection with waning antibody titers, or false results.

For almost $25 \mathrm{yr}$, no case reports or prevalence studies were published, to our knowledge, regarding $L$. interrogans in animals of Larimer County, Colorado, USA. However, between 2005 and 2008, a growing number of domestic dogs in Colorado, USA, were diagnosed with leptospirosis; $61 \%$ of those were dogs living in urban or suburban environments, including Larimer County, Colorado, USA, where there were 85 suspected and 15 confirmed cases; Grippotyphosa was the most commonly reported serovar (Veir 2009). Many peridomestic animals also live in these environments, including Norway rats (Rattus norvegicus), mice (Mus musculus), raccoons, and fox squirrels. Previous studies in Larimer County, Colorado, USA, have shown evidence of L. interrogans infection in Norway rats, house mice, and raccoons (Roberts 1972; Al Saadi and Post 1976; Duncan et al., 2012). Although fox squirrels in Colorado, USA, have not been investigated until this study, to our knowledge, a gray squirrel (Sciurus carolinensis) from Connecticut, USA, had antibodies to L. interrogans 


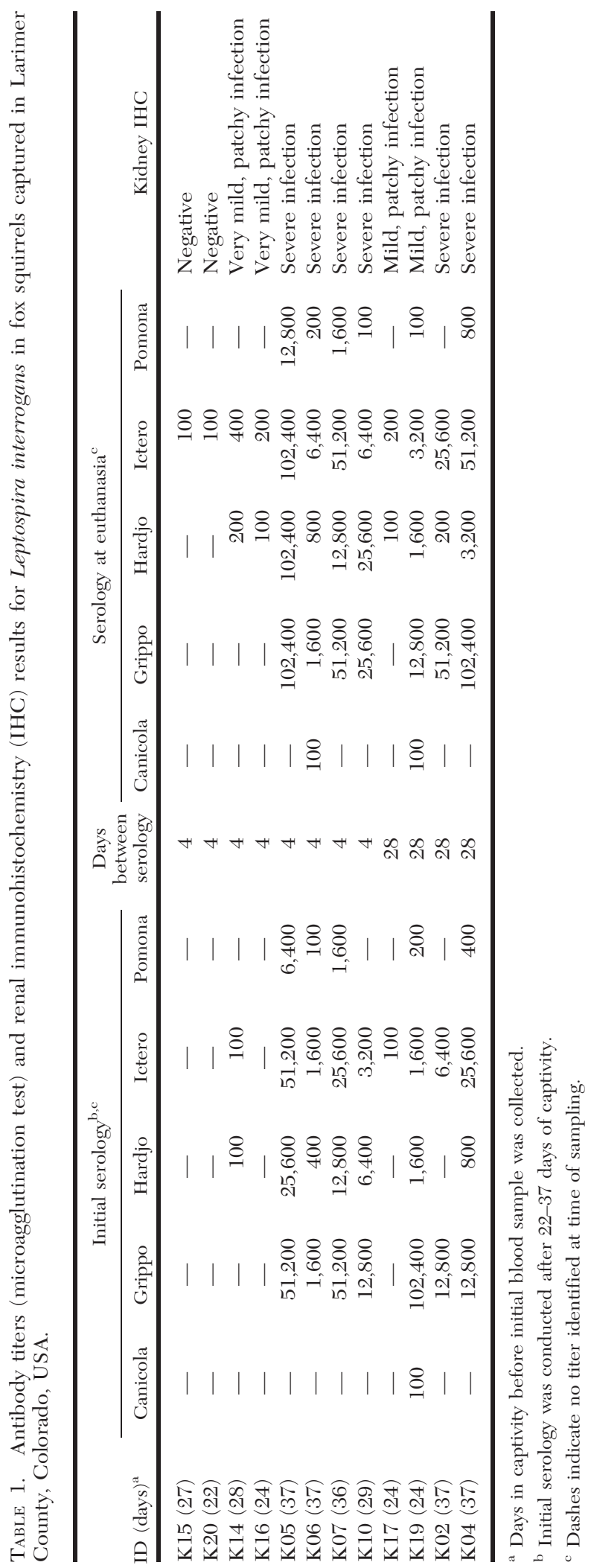


serovars Grippotyphosa and Canicola (Richardson and Gauthier, 2003). Similarly, L. interrogans serovar Grippotyphosa has been isolated from the kidneys of five southern flying squirrels (Glaucomys volans) and was subsequently identified in two human handlers, demonstrating the potential for zoonotic transmission (Masuzawa et al., 2006).

We provide evidence of $L$. interrogans infection, with both mild and severe renal disease, in a population of peridomestic fox squirrels in Larimer County, Colorado, USA. The high prevalence of disease $(45 \%)$ and antibody-positive animals $(55 \%)$ was unexpected and suggests that fox squirrels may be important in the epidemiology of leptospirosis in the region. Although the causative serovar cannot be unequivocally determined, the high antibody titers suggest probable infection with serovars Grippotyphosa, Hardjo, or Icterohaemorrhagiae. Many species of rodents are considered reservoirs of L. interrogans; therefore, squirrels may be important hosts in the maintenance and transmission of $L$. interrogans in some regions. Although the course of infection with $L$. interrogans is unknown, the squirrels in this study were captured in urban and suburban areas, and the epidemiology of leptospirosis in fox squirrels and increased incidence in dogs may be related. The possibility of squirreldog transmission warrants further investigation to better understand the spread of leptospirosis at the urban-wildlife interface.

We thank Daniel Gossett and the animal care staff at the National Wildlife Research Center for their help in completing this research, and Cindy Hirota for assistance with serology.

\section{LITERATURE CITED}

Al Saadi M, Post G. 1976. Rodent leptospirosis in Colorado. J Wildl Dis 12:315-317.

Bharti AR, Nally J, Ricaldi J, Matthias M, Diaz MM, Lovett MA, Levett PN, Gilman RH, Willig MR, Gotuzzo E, et al. 2003. Leptospirosis: A zoonotic disease of global importance. Lancet Infect Dis 3:757-771.

Duncan C, Krafsur G, Podell B, Baeten LA. 2012. Leptospirosis and tularaemia in raccoons (Procyon lotor) of Larimer County, Colorado. Zoonoses Public Health 59:29-34.

Gautam R, Guptill LF, Wu CC, Potter A, Moore GE. 2010. Spatial and spatio-temporal clustering of overall and serovar-specific Leptospira microscopic agglutination test (MAT) seropositivity among dogs in the United States from 2000 through 2007. Prev Vet Med 96:122-131.

Lau C, Smythe L, Weinstein P. 2009. Leptospirosis: an emerging disease in travelers. Travel Med Infect Dis 8:33-39.

Masuzawa T, Okamoto Y, Une Y, Takeuchi T. 2006. Leptospirosis in squirrels imported from United States to Japan. Emerg Infect Dis 12:1153-1155.

Monahan AM, Callanan JJ, Nally JE. 2009. Review paper: Host-pathogen interactions in the kidney during chronic leptospirosis. Vet Pathol 46:792799.

Roberts JR. 1972. Factors influencing growth, virulence, viability, and antigenicity of Leptospira icterohaemorrhagiae. MS Thesis. Colorado State University, Fort Collins, Colorado, 310 pp.

Richardson DJ, Gauthier JL. 2003. A serosurvey of leptospirosis in Connecticut peridomestic wildlife. Vector Borne Zoonotic Dis 3:187-193.

Veir J. 2009. Take a new look at canine lepto in Colorado. Colo Vet Med Assoc Voice 2. http:// www.colovma.com/associations/2956/files/ CVMA\%20Voice\%20Lepto\%20story_FIN.pdf. Accessed February 2013.

Submitted for publication 24 October 2012. Accepted 12 January 2013. 